\title{
Cooperative Effect between Recombinant Mouse IL-6 or Recombinant Human IL-1 and Glucagon on $\alpha$-Aminoisobutyric Acid Uptake and Phosphoenolpyruvate Carboxykinase Activity in Cultured Rat Hepatocytes
}

\author{
Hidenori Miyake, ${ }^{1, *}$ Hiroo TAKehara, ${ }^{1}$ and Fletcher Starnes, JR. ${ }^{2}$ \\ ${ }^{1}$ The First Department of Surgery, School of Medicine, The University of Tokushima, \\ Tokushima 770, Japan \\ ${ }^{2}$ Department of Surgery, Stanford University Medical Center, Stanford University School of \\ Medicine, Stanford, CA 94305-5101, U.S.A.
}

(Received December 29, 1993)

\begin{abstract}
Summary $\quad \alpha$-Amino $\left[1-{ }^{14} \mathrm{C}\right]$ isobutyric acid $\left(\left[{ }^{14} \mathrm{C}\right] \mathrm{AIB}\right)$ is a non-metabolizable analogue of alanine, the principal amino acid released by muscle in catabolic states and the major gluconeogenic amino acid in the liver. Phosphoenolpyruvate carboxykinase (PEPCK) is a rate-limiting enzyme in gluconeogenesis. Many factors, such as hormones and cytokines, have effect on both uptake of alanine by the liver and the hepatic PEPCK activity. The aim of this study was to evaluate the cooperative effect of recombinant mouse IL-6 (rmIL-6) and recombinant human IL-1 (rhIL-1) with glucagon on $\left[{ }^{14} \mathrm{C}\right] \mathrm{AIB}$ uptake and PEPCK activity in cultured rat hepatocytes. Our data showed that rmIL-6 and glucagon increased $\left[{ }^{14} \mathrm{C}\right]-$ AIB uptake individually in a dose-dependent manner and had a significant additive effect on the uptake in rat hepatocytes. However, rhIL-1 had no effect on $\left[{ }^{14} \mathrm{C}\right]$ AIB uptake. Regarding PEPCK, rmIL-6 and rhIL-1 had no effect on the activity of PEPCK in rat hepatocytes. But both rmIL-6 and rhIL-1 significantly inhibited the stimulative effect of glucagon on hepatic PEPCK activity of the rats.
\end{abstract}

Key Words: interleukin 6, interleukin 1, phosphoenolpyruvate carboxykinase, amino isobutyric acid, cultured rat hepatocytes

The acute-phase response of liver cells involves changes in the hepatocyte enzymic pattern, accumulation of iron and zinc, enhanced uptake of some amino acids, and increased synthesis of RNA accompanied by a profound rearrangement

\footnotetext{
* To whom correspondence should be addressed.
} 
of plasma protein synthesis. In such conditions, amino acid uptake by liver cells and hepatic gluconeogenic enzymes are strongly controlled by certain hormones and cytokines. Not only IL-6 but also IL-1 plays a central role in the acute-phase response in the liver. Also glucagon is one of the most important stress hormones, controlling amino acid uptake by the liver and induction of PEPCK, a ratelimiting enzyme in gluconeogenesis, in the liver cells. Many results have been reported about the actions of these cytokines and hormones on the acute-phase response. Glucagon is a stimulator of hepatic AIB transport both in vivo [1] and in vitro [2]. rhIL-6 increased AIB uptake of rat hepatocytes [3], and purified IL-1 stimulated alanine transport in rat hepatocytes [4]. PEPCK was shown to be positively regulated by glucagon, primarily because it increased the transcription rate of the gene $[5,6]$. Recombinant human IL-1 and tumor necrosis factor (TNF), as well as purified murine IL-6, have been shown to decrease PEPCK enzyme activity in Reuber hepatoma cells [7,8]. Rabbit IL-1 treatment inhibited the induction of PEPCK in fasted mice [9]. Furthermore, hyperglucagonemia failed to prevent the decrease in PEPCK gene expression due to endotoxin in the endotoxic rat [10]. And despite the high levels of circulating glucagon, PEPCK enzymes were depressed [9]. Transformed hepatoma cell lines manifest abnormal metabolic behavior and do not respond to hormones as a normal liver in vivo or isolated hepatocytes; and, also, many factors other than IL-6, IL-1 and glucagon participate in the acute-phase response. Even so, no reports have appeared about the direct interaction between such cytokines and glucagon on AIB uptake and PEPCK enzyme activity in cultured rat hepatocytes. Therefore, we decided to evaluate directly such cooperative effect of IL-1, IL-6 with glucagon on AIB uptake and PEPCK enzyme activity by using rat hepatocytes.

\section{MATERIALS AND METHODS}

Chemicals. $\left[{ }^{14} \mathrm{C}\right] \mathrm{AIB}(50 \mathrm{mCi} / \mathrm{mmol})$ and $\mathrm{NaH}^{14} \mathrm{CO}_{3}(56 \mathrm{mCi} / \mathrm{mmol})$ were purchased from ICN Biochemicals Inc. (Irvine, CA). Dulbecco's modified Eagle's medium (DMEM), dexamethasone, insulin, collagen type 1, penicillin and streptomycin $(\mathrm{P} / \mathrm{S})$, glutamine, imidazole inosine diphosphate, manganese chloride, gluthathione, $\beta$-nicotinamide adenine dinucleotide [reduced form], malate dehydrogenase, phosphoenolpyruvate, hydrochloric acid, sucrose, and trizama hydrochloride were from Sigma Chemical Co. (St. Louis, MO). Glucagon was from Eli Lilly \& Co. (Indianapolis, IN), fetal bovine serum (heat inactivated), from GEMINI Bioproducts Inc. (Colabasas, CA), and recombinant $E$. coli-derived human IL-1 $\beta$ (rhIL-1 $\beta, 20 \mathrm{mg} / \mathrm{ml}$ ), from SYNTEX (Palo Alto, CA). Recombinant CHO (Chinese Hamster Ovary) cell-derived murine IL-6 (rmIL-6, $189 \mathrm{mg}$ ) ml) was obtained from DNAX (Palo Alto, CA).

Hepatocyte culture. Hepatocytes were isolated from the livers of adult Fischer 344 rats after perfusion with collagenase by the procedure of Seglen [11]. For AIB uptake experiments, the cells had been washed 3 times with DMEM 
containing $0.005 \%$ DNAse, they were resuspended in a DMEM containing $10 \%$ fetal bovine serum, $1 \mathrm{~mm}$ dexamethasone, $1 \mathrm{~mm}$ insulin, $2 \mathrm{~mm}$ glutamine, $500 \mathrm{U} / \mathrm{ml}$ penicillin $\mathrm{G}$, and $50 \mathrm{mg} / \mathrm{ml}$ streptomycin. Hepatocyte monolayers were obtained by pipetting $2.5 \times 10^{5}$ cells/ well into 24 -well flat bottom multidishes. For PEPCK enzyme activity assay experiments, after the cells had been washed with DMEM containing $0.005 \%$ DNAse, they were resuspended in a DMEM containing $4 \%$ fetal bovine serum, $1 \mathrm{~mm}$ dexamethasone, $1 \mathrm{~nm}$ insulin (low level added to improve culture maintenance), $2 \mathrm{~mm}$ glutamine, $500 \mathrm{U} / \mathrm{ml}$ penicillin $\mathrm{G}$, and $50 \mathrm{mg} / \mathrm{ml}$ streptomycin. Hepatocyte monolayers were obtained by pipetting $10^{6}$ cells/well into 6-well flat bottom multidishes. All multidishes were purchased from Applied Scientific (San Francisco, CA) and coated with collagen in advance.

Measurement of $\left[{ }^{14} \mathrm{C}\right] A I B$ uptake. Four hours after the cells had been pipetted into multidishes, the medium was aspirated and replaced with fresh medium of the same type. Twenty hours later the medium was changed to that without insulin and dexamethasone but containing cytokines, and incubation was continued for $20 \mathrm{~h}$. Then, glucagon was added to some of the cultures, and incubation was continued for $6 \mathrm{~h}$. Next, the medium was aspirated, and $0.5 \mathrm{mCi}$ / $\mathrm{ml}\left[{ }^{14} \mathrm{C}\right] \mathrm{AIB}$ was added. Uptake was then allowed to proceed at $37^{\circ} \mathrm{C}$ for $20 \mathrm{~min}$, as this amount of time was shown earlier to be sufficient [12]. After incubation the medium was aspirated; and the cells were washed 3 times with PBS, after which they were incubated with $100 \mu 1$ of trypsin-EDTA for $20 \mathrm{~h}$. Then the cells were scraped off the dishes and transferred to scintillation vials. One hundred microliters of $0.1 \mathrm{~N} \mathrm{NaOH}$ was added to the dishes and the remaining cells were scraped off the dishes again and transferred to the same scintillation vials. Three or four milliliters of scintillation liquid was added, and the samples were counted for ${ }^{14} \mathrm{C}$ by liquid scintillation spectrometry. All results were expressed as a ratio to the controls, which were incubated without cytokines or glucagon.

Measurement of PEPCK enzyme activity. Four hours after the cells had been pipetted into dishes, the medium was aspirated and replaced with fresh medium containing $500 \mathrm{U} / \mathrm{ml}$ penicillin $\mathrm{G}, 50 \mathrm{mg} / \mathrm{ml}$ streptomycin, $2 \mathrm{~mm}$ glutamine, $1 \mathrm{~nm}$ insulin, and $1 \mathrm{~nm}$ dexamethasone. Twenty hours later, the medium was replaced again with fresh medium of the same type. Cytokines and glucagon were added, and incubation was carried out for $4 \mathrm{~h}$, because maximal enzyme activity was earlier shown to be reached after 4 to $6 \mathrm{~h}$ following glucagon addition [13]. After aspiration of the medium, the cells were harvested in Tris-sucrose and collected into centrifugation tubes. The cells were sedimented in an ultracentrifuge (Beckman Model L8-7) at 230,000 $\times g$ and $4^{\circ} \mathrm{C}$ for $30 \mathrm{~min}$, and the supernatant was removed and kept on ice. The assay mixture was modified from that described for the ${ }^{14} \mathrm{CO}_{2}$ fixation assay by Huei and Lane [14]. The mixture contained $500 \mathrm{~mm}$ imidazole hydrochloric acid, $12.5 \mathrm{~mm}$ imidazole inosine diphosphate, $10 \mathrm{~mm}$ manganese chloride, $20 \mathrm{~mm}$ gluthathione, $25 \mathrm{~mm} \beta$-nicotinamide adenine dinucleotide [reduced form], 5-10 U/ml malate dehydrogenase, $25 \mathrm{~mm}$ phosphoenolpyruvate, and $100 \mathrm{mCi} / \mathrm{ml} \mathrm{NaH}{ }^{14} \mathrm{CO}_{3}$. One hundred microliters of assay mixture

Vol. 17, No. 1, 1994 
and cytosol were mixed and warmed to $37^{\circ} \mathrm{C}$, and the reaction was initiated by the addition of $15 \mu \mathrm{l}$ of phosphoenolpyruvate. Fifteen minutes later, the reaction was terminated by addition of $30 \mu 1$ of $2 \mathrm{~N}$ hydrochloric acid. The entire mixture was spotted on a paper disc and allowed to dry overnight in a hood for removal of excess ${ }^{14} \mathrm{CO}_{2}$. Each disc was then placed in a scintillation vial, scintillation liquid was added, and the sample was counted for ${ }^{14} \mathrm{C}$ in a liquid scintillation spectrometer. Remainder of the cytosol fraction was kept in a freezer until measurement of cytosol protein was made by use of a Bio-Rad Protein Assay kit (BIO-RAD, Richmond, CA). Enzyme activity was calculated as units per cytosol protein corresponding to nanomoles of oxaloacetate formed per $15 \mathrm{~min}$ per $\mathrm{mg}$ of cytosol protein, and all results were expressed as a ratio to the controls, which were cultured without cytokines and glucagon.

Animals. Male Fischer 344 rats (Simson Labs., Gilroy, CA) weighing 200$300 \mathrm{~g}$ were housed in a temperature-controlled room with alternating $12 \mathrm{~h}$ lightdark cycles and allowed free access to standard laboratory chow (Ralston Purina, St. Louis, MO) and water. The experimental protocols used were reviewed and approved by the Animal Care and Use Panel at Stanford University Medical Center.

Statistics. Statistical analysis of the data was performed by means of analysis of variance (ANOVA) with a personal computer (Macintosh IIci and Statview II software; Apple Computer Inc., Cupertino, CA) and significance defference was defined as $p<0.05$.

\section{RESULTS}

\section{Effect of rmIL-6 and rhIL-1 on $\left[{ }^{14} C\right] A I B$ uptake in rat hepatocytes}

Rat hepatocytes were incubated with various concentrations of rmIL-6 or rhIL-1 for $20 \mathrm{~h}$. rmIL- 6 stimulated $\left[{ }^{14} \mathrm{C}\right] \mathrm{AIB}$ uptake in rat hepatocytes in a dose-dependent manner. Especially, above $1 \mathrm{ng} / \mathrm{ml}$, rmIL-6 significantly increased $\left[{ }^{14} \mathrm{C}\right] \mathrm{AIB}$ uptake compared with that of the control. But rhIL-1 had no significant effect on $\left[{ }^{14} \mathrm{C}\right] \mathrm{AIB}$ uptake in rat hepatocytes (Table 1).

Table 1. AIB uptake by rat hepatocytes incubated with various concentrations of rmIL-6 or rhIL-1.

\begin{tabular}{|c|c|c|c|}
\hline \multicolumn{2}{|c|}{ IL-6 } & \multicolumn{2}{|c|}{ IL-1 } \\
\hline Concentration $(\mathrm{ng} / \mathrm{ml})$ & Ratio to control & Concentration $(\mathrm{ng} / \mathrm{ml})$ & Ratio to control \\
\hline $0.1 \quad(n=20)$ & $1.01 \pm 0.02$ & $0.1 \quad(n=10)$ & $0.92 \pm 0.04$ \\
\hline $1.0(n=22)$ & $1.15 \pm 0.03^{*}$ & $1.0(n=13)$ & $1.01 \pm 0.05$ \\
\hline $10 \quad(n=24)$ & $1.59 \pm 0.07^{*}$ & $10 \quad(n=13)$ & $1.04 \pm 0.06$ \\
\hline $50 \quad(n=8)$ & $1.76 \pm 0.08^{*}$ & $50 \quad(n=3)$ & $0.80 \pm 0.09$ \\
\hline $100(n=20)$ & $1.84 \pm 0.10^{*}$ & $100(n=12)$ & $1.00 \pm 0.08$ \\
\hline
\end{tabular}

The results are the means \pm SEM expressed as a ratio to the controls, which were incubated without IL-6 and IL-1 (control cultures without IL- 6 or IL-1 $=1.0$ ) ${ }^{*} p<0.05$ vs. control by ANOVA. 
EFFECT OF IL-6, IL-1 AND GLUCAGON ON AIB UPTAKE AND PEPCK 5 Interaction between rmIL-6 or rhIL-1 and glucagon on $\left[{ }^{14} C\right]$ AIB uptake in rat hepatocytes

Rat hepatocytes were incubated with or without various concentrations of cytokines for $20 \mathrm{~h}$, and then $1 \mathrm{~nm}$ or $10 \mathrm{~nm}$ of glucagon was added and incubation continued for $6 \mathrm{~h}$. One nanomolar and $10 \mathrm{~nm}$ glucagon increased $\left[{ }^{14} \mathrm{C}\right] \mathrm{AIB}$ uptake in rat hepatocytes 1.5 -fold and 2.5-fold, respectively, compared with the control uptake. rmIL-6 had a dose-dependent additive effect on stimulation of $\left[{ }^{14} \mathrm{C}\right] \mathrm{AIB}$ uptake by glucagon. Especially, above $10 \mathrm{ng} / \mathrm{ml}$, rmIL-6 had significant $(p<0.05)$ additive effect (1.6-fold vs. 2.1-fold, 2.6-fold vs. 3.6-fold, 2.6-fold vs. 3.9-fold, for glucagon $1 \mathrm{~nm}$ vs. glucagon $1 \mathrm{nM}+$ IL-6 $100 \mathrm{ng} / \mathrm{ml}$, glucagon $10 \mathrm{~nm}$ vs. glucagon 10 $\mathrm{nM}+\mathrm{IL}-610 \mathrm{ng} / \mathrm{ml}$, glucagon $10 \mathrm{~nm}$ vs. glucagon $10 \mathrm{~nm}+\mathrm{IL}-6100 \mathrm{ng} / \mathrm{ml}$, respectively; Table 2). rhIL-1 had no effect on stimulation of $\left[{ }^{14} \mathrm{C}\right]$ AIB uptake by glucagon in rat hepatocytes (Table 3).

\section{Effect of rmIL-6 and rhIL-1 on PEPCK activity in rat hepatocytes}

When rat hepatocytes were incubated with various concentrations of rmIL-6 or rhIL-1 for $4 \mathrm{~h}$, neither cytokine had a significant effect on PEPCK activity compared with the control value (Table 4).

Table 2. AIB uptake by rat hepatocytes cultured with $1 \mathrm{nM}$ or $10 \mathrm{~nm}$ glucagon and various concentrations of rmIL-6.

\begin{tabular}{ccccc}
\hline \multicolumn{2}{c}{ l nM glucagon } & & \multicolumn{2}{c}{$10 \mathrm{nM}$ glucagon } \\
\cline { 1 - 2 } $\begin{array}{c}\text { Concentration of IL-6 } \\
(\mathrm{ng} / \mathrm{ml})\end{array}$ & Ratio to control & & $\begin{array}{c}\text { Concentration of IL-6 } \\
(\mathrm{ng} / \mathrm{ml})\end{array}$ & Ratio to control \\
\hline $0 \quad(n=13)$ & $1.55 \pm 0.14$ & & $0 \quad(n=15)$ & $2.55 \pm 0.17$ \\
$0.1(n=6)$ & $1.24 \pm 0.11$ & & $0.1(n=9)$ & $3.13 \pm 0.26$ \\
$1.0(n=6)$ & $1.43 \pm 0.12$ & & $1.0(n=9)$ & $3.10 \pm 0.28$ \\
$10(n=6)$ & $1.66 \pm 0.14$ & & $10(n=9)$ & $3.64 \pm 0.34^{* *}$ \\
$100(n=6)$ & $2.11 \pm 0.22^{*}$ & & $100(n=9)$ & $3.89 \pm 0.54^{* *}$ \\
\hline
\end{tabular}

The results are the means \pm SEM expressed as a ratio to the controls, which were incubated without glucagon and rmIL-6 (control cultures without glucagon and IL- $6=1.0$ ). ${ }^{*} p<0.05$ vs. $1 \mathrm{~nm}$ glucagon alone and ${ }^{*} p<0.05$ vs. $10 \mathrm{~nm}$ glucagon alone by ANOVA.

Table 3. AIB uptake by rat hepatocytes cultured with $1 \mathrm{nM}$ or $10 \mathrm{~nm}$ glucagon and various concentrations of rhIL-1.

\begin{tabular}{ccccc}
\hline \multicolumn{2}{c}{ 1 nM glucagon } & & \multicolumn{2}{c}{$10 \mathrm{nM}$ glucagon } \\
\cline { 1 - 2 } $\begin{array}{c}\text { Concentration of IL-1 } \\
(\mathrm{ng} / \mathrm{ml})\end{array}$ & Ratio to control & & $\begin{array}{c}\text { Concentration of IL-1 } \\
(\mathrm{ng} / \mathrm{ml})\end{array}$ & Ratio to control \\
\hline $0 \quad(n=13)$ & $1.55 \pm 0.14$ & $0 \quad(n=15)$ & $2.55 \pm 0.17$ \\
$0.1(n=3)$ & $1.31 \pm 0.22$ & & $0.1(n=5)$ & $2.61 \pm 0.36$ \\
$1.0(n=3)$ & $1.51 \pm 0.08$ & & $1.0(n=5)$ & $2.54 \pm 0.36$ \\
$10(n=3)$ & $1.37 \pm 0.03$ & & $10(n=5)$ & $2.72 \pm 0.35$ \\
$100(n=3)$ & $1.24 \pm 0.14$ & & $100(n=5)$ & $2.00 \pm 0.12$ \\
\hline
\end{tabular}

The results are the means \pm SEM expressed as a ratio to the controls, which were incubated without glucagon and rhIL-1 (control cultures without glucagon and rhIL-1=1.0). 
Table 4. PEPCK activity in rat hepatocytes cultured with various concentrations of rmIL-6 or rhIL-1.

\begin{tabular}{ccccc}
\hline \multicolumn{2}{c}{ rmIL-6 } & & \multicolumn{2}{c}{ rhIL-1 } \\
\cline { 1 - 2 } Concentration $(\mathrm{ng} / \mathrm{ml})$ & Ratio to control & & Concentration $(\mathrm{ng} / \mathrm{ml})$ & Ratio to control \\
\hline $1.0(n=3)$ & $0.93 \pm 0.04$ & & $1.0(n=3)$ & $0.95 \pm 0.07$ \\
$10(n=8)$ & $0.94 \pm 0.06$ & & $10(n=9)$ & $1.05 \pm 0.04$ \\
$100(n=8)$ & $1.11 \pm 0.08$ & & $100(n=10)$ & $1.09 \pm 0.05$ \\
\hline
\end{tabular}

The results are the means \pm SEM expressed as a ratio to the controls, which were incubated without rmIL-6 and rhIL-1 (control cultures without rmIL-6 and rhIL-1 $=1.0$ ).

Table 5. PEPCK activity in rat hepatocytes cultured with $100 \mathrm{~nm}$ glucagon and various concentrations of rmIL-6 or rhIL-1.

\begin{tabular}{ccccc}
\hline \multicolumn{2}{c}{$100 \mathrm{nM}$ glucagon + rmIL-6 } & & \multicolumn{2}{c}{$100 \mathrm{~nm}$ glucagon + rhIL-1 } \\
\cline { 2 - 2 } $\begin{array}{c}\text { Concentration of IL-6 } \\
(\mathrm{ng} / \mathrm{ml})\end{array}$ & Ratio to control & & $\begin{array}{c}\text { Concentration of IL-1 } \\
(\mathrm{ng} / \mathrm{ml})\end{array}$ & Ratio to control \\
\hline $0 \quad(n=25)$ & $2.15 \pm 0.12$ & & $0 \quad(n=25)$ & $2.15 \pm 0.12$ \\
$1.0(n=3)$ & $1.79 \pm 0.19$ & & $1.0(n=3)$ & $1.65 \pm 0.16$ \\
$10(n=8)$ & $1.76 \pm 0.25$ & & $10(n=5)$ & $1.56 \pm 0.10^{*}$ \\
$100(n=8)$ & $1.41 \pm 0.12^{*}$ & & $100(n=5)$ & $1.49 \pm 0.06^{*}$ \\
\hline
\end{tabular}

The results are the means \pm SEM expressed as a ratio to the controls, which were incubated without glucagon and rmIL-6 or rhIL-1 (control cultures without glucagon, rmIL-6, and rhIL-1 $=1.0) .{ }^{*} p<0.05$ vs. $100 \mathrm{~nm}$ glucagon alone by ANOVA.

Interaction between rmIL-6 or rhIL-1 and glucagon on PEPCK activity in rat hepatocytes

Rat hepatocytes were incubated with $100 \mathrm{~nm}$ glucagon with or without various concentrations of cytokines for $4 \mathrm{~h}$. rmIL-6 decreased the stimulative effect of glucagon on PEPCK activity in a dose-dependent fashion. One hundred nanograms per $\mathrm{ml}$ of rmIL-6 significantly inhibited the glucagon-stimulated PEPCK enzyme activity ( 2.2-fold vs. 1.4-fold, for glucagon $100 \mathrm{~nm}$ vs. glucagon $100 \mathrm{nM}+\mathrm{IL}-6100 \mathrm{ng} / \mathrm{ml}, p<0.05)$. rhIL-1 also had an inhibitory effect on glucagon-stimulated PEPCK activity. At both $10 \mathrm{ng}$ per $\mathrm{ml}$ and $100 \mathrm{ng}$ per $\mathrm{ml} \mathrm{rhIL}-1$ significantly $(p<0.05)$ decreased PEPCK enzyme activity induced by glucagon (2.2-fold vs. 1.6-fold, and 2.2-fold vs. 1.5-fold, for glucagon $100 \mathrm{~nm}$ vs. glucagon $100 \mathrm{nM}+\mathrm{IL}-110 \mathrm{ng} / \mathrm{ml}$, and glucagon $100 \mathrm{~nm}$ vs. glucagon $100 \mathrm{nM}+\mathrm{IL}-1100 \mathrm{ng} /$ $\mathrm{ml}$, respectively; Table 5).

\section{DISCUSSION}

Interleukin-6 (IL-6, also called interferon $\beta_{2}, 26 \mathrm{kDa}$ protein, B-cell stimulatory factor, hepatocyte stimulating factor) and interleukin-1 (IL-1) share a number of biological activities including induction of fever, neutrophilia, and acute-phase response. Glucagon is also one of the most important stress hormones in such conditions. The purpose of these experiments was to investigate the 
cooperative effect between IL-1 or IL-6, which play an important role in the hepatic acute-phase response, and glucagon on the AIB uptake and PEPCK enzyme activity in rat hepatocytes.

In rat hepatocytes isolated after intraperitoneal injection of purified IL-1, alanine uptake was increased [4]. Also an in vivo experiment showed that purified human monocyte-derived IL-1 [15] and rhIL-1 [16] increased hepatic AIB uptake [15]. But in vitro, rhIL-1 failed to stimulate hepatocyte AIB transport [17], a result that agrees with our present findings. rhIL-6 not only increased some positive acute proteins but also enhanced AIB accumulation in rat hepatocytes in a dose-dependent manner $[3,12,18]$. Glucagon greatly stimulated AIB uptake, but had no significant effect on acute-phase proteins [15]. We found an additive effect of glucagon and IL-6 on the AIB uptake (Table 2). But in our experiments IL-1 had no effect on the AIB uptake (Tables 1,3), which findings disagree with previous observations $[4,15,16]$. It is likely that in both in vivo experiments and in the case of hepatocytes isolated after injection of IL-1, the hepatic effects of IL-1 may be mediated via some other hormones or cytokines.

In the liver cytosolic PEPCK reaction, actually at least 97\% of PEPCK activity is located in the cytosol of the rat liver [19], and this reaction is an important one contributing to the control of the rate of gluconeogenesis from, for example, lactate or alanine in the acute-phase response. Recent studies have shown that glucocorticoid and thyroid hormones predominantly enhanced the cAMPprovoked induction of hepatic PEPCK mRNA and, consequently, of PEPCK synthesis [20]. But glucagon is the single most effective inducer and causes a 15-20 fold increase in the level of specific mRNA in $2 \mathrm{~h}$, accompanied by a similar increase in the enzyme synthesis rate in rat hepatocytes [21]. Although insulin has been considered as a dominant hormone for the regulation of the PEPCK induction in H4IIE hepatoma cells [22-24], glucagon is the dominant hormone in primary rat hepatocyte cultures [25]. Purified rabbit IL-1 decreased the intracellular steroid receptor, resulting in decreased induction of PEPCK and subsequently reduced gluconeogenesis and plasma glucose in $\mathrm{C} 3 \mathrm{H} / \mathrm{HeJ}$ mice [9]. Furthermore, human recombinant IL-1 used in vitro reduced cytosolic glucocorticoid binding in Reuber hepatoma cells [26]. Purified murine IL-6 inhibited the hormonal (dexamethasone, chlorophenylthio-cAMP and isobutyl methylxanthine) induction of PEPCK mRNA and enzyme activity in Reuber hepatoma cells, and this inhibition may be mediated via protein kinase $C[10]$. It was surprising to us that interaction between IL-1 or IL- 6 and glucagon had been previously examined only in hepatoma cell lines or in vivo experiments $[7,10]$. Our experiment was designed to investigate the direct cooperative effect between IL-1 or IL-6 and glucagon on the PEPCK enzyme activity in rat hepatocytes. The results we obtained were that IL-1 and IL- 6 had no direct effect on PEPCK enzyme activity individually compared with the controls (Table 4). But when hepatocytes were cultured with IL-1 or IL-6 and glucagon, IL-1 and IL-6 inhibited the glucagonstimulated PEPCK enzyme activity (Table 5). These results agree with previous 
observations (in vitro and in vivo experiments) in which IL-1 and IL-6 were found to decrease the induction of PEPCK. Our results showed directly that IL-6 and IL-1 decreased the hepatic PEPCK activity by inhibiting glucagon action, and this action of IL-6 and IL-1 may be responsible for the low blood glucose level seen in the acute-phase response. More investigation is necessary to clarify how IL-1 and IL-6 can inhibit the glucagon effect on PEPCK induction and to determine if a cooperative effect between these cytokines and other hormones can be demonstrated in cultured rat hepatocytes.

Our results confirmed that IL-1 had no effect on alanine uptake but that IL-6 stimulated alanine uptake in a dose-dependent manner by itself. We showed also that IL-6 and glucagon had an additive effect on alanine uptake in rat hepatocytes. Furthermore, neither IL-1 nor IL-6 had any effect on PEPCK activity when tested alone, but both inhibited the stimulative effect of glucagon on PEPCK activity in the rat hepatocytes.

\section{REFERENCES}

1. Kilberg, M.S., and Neuhaus, O.D. (1977): Hormonal regulation of amino acid transport. $J$. Supramol. Struct., 6, 191-204.

2. Kletzein, R.F., Pariza, M.W., Becker, J.E., and Potter, V.R. (1975): A permissive effect of dexamethasone on the glucagon induction of amino acid transport in cultured hepatocytes. Nature Lond., 256, 46-47.

3. Rokita, H., Bereta, J., Koj, A., Gordon, A.H., and Gaudie, J. (1990): Epidermal growth factor and transforming growth factor- $\beta$ differently modulate the acute phase response elicited by interleukin-6 in cultured liver cells from man, rat and mouse. Comp. Biochem. Physiol., 95A, 41-45.

4. Mark, S.R., Moldawer, L.L., Ekman, L.G., Dinarello, C.A., and Bristrian, B.R. (1986): Stimulatory effect of interleukin-1 upon hepatic metabolism. Metab. Clin. Exp., 35, 419424.

5. Gunn, J., Hanson, R., Meyuhas, O., Reshef, L., and Ballard, J. (1975): Glucocorticoids and the regulation of phosphoenolpyruvate carboxykinase (guanosine triphosphate) in the rat. Biochem. J., 150, 195-203.

6. Gunn, J.M., Tilghman, S.M., Hanson, R.W., Reshef, L., and Ballard, F.J. (1975): Effects of cyclic adenosine monophosphate, dexamathasone, and insulin on phosphoenolpyruvate carboxykinase synthesis in Reuber H-35 hepatoma cells. Biochemistry, 14, 2350-2357.

7. Molly, R.H., Stith, R.D., and McCallum, R.E. (1989): Mechanism of action of interferon- $\beta_{2} /$ interleukin-6 on induction of hepatic liver enzymes. Ann. N.Y. Acad. Sci., 557, 502-505.

8. McCallum, R.E., Molly, R.H., and Stith, R.D. (1988): Inhibited steroid induction of PEPCK in hepatoma cells treated with HurIL-1 and HurTNF, in Monokines and Other Non-Lymphocytic Cytokines, ed. by Powanda, M.C., Alan R. Liss, Inc., New York, pp. 267-272.

9. Molly, R.H., Stith, R.D., and McCallum, R.E. (1986): Interleukin 1: A regulatory role in glucocorticoid-regulated hepatic metabolism. J. Immunol., 137, 858-862.

10. Molly, R.H., and McCallum, R.E. (1991): Altered transcriptional regulation of phosphoenolpyruvate carboxykinase in rats following endotoxin treatment. J. Clin. Invest., 88, 811-816.

11. Seglen, P.O. (1973): Preparation of rat liver cells. III. Enzymatic requirements for tissue dispersion. Expl. Cell Res., 82, 391-398.

12. Bereta, J., Kurdowska, A., Koj, A., Hirano, T., Kishimoto, T., Content, J., Fiers, W., 
Damme, J., and Gauldie, J. (1989): Different preparations of natural and recombinant human interleukin-6 (IFN- $\beta_{2}$, BSF-2) similarly stimulate acute phase protein synthesis and uptake of $\alpha$-aminoisobutyric acid by cultured rat hepatocytes. Int. J. Biochem., 21, 361-366.

13. Josef, H., Christ, B., Bastian, H., and Jungermann, K. (1991): Modulation by oxygen of the glucagon-dependent activation of the phosphoenolpyruvate carboxykinase gene in the rat hepatocytes. Eur. J. Biochem., 198, 635-639.

14. Huei, C.C., and Lane, M.D. (1966): The enzymatic carboxylation of phosphoenolpyruvate. II. Purification and properties of liver mitochondrial phosphoenolpyruvate carboxykinase. J. Biol. Chem., 241, 2413-2420.

15. Robert, S.W., Starnes, H.F., Alcock, N., Calvano, S., and Brennan, M.F. (1988): Hormonal and metabolic response to recombinant human tumor necrosis factor in rat: In vivo and in vitro. Am. J. Physiol., 255, E206-E212.

16. Argiles, J.M., Lopez-Soriano, F.J., Wiggins, D., and Williamson, D.H. (1989): Comparative effects of tumor necrosis factor- $\alpha$ (cachectin), interleukin-1- $\beta$ and tumor growth on amino acid metabolism in the rat in vivo. Biochem. $J$., 261, 357-362.

17. Robert, S.W., Donner, D.B., Starnes, H.F., and Brennan, M.F. (1987): Modulation of endogenous hormone action by recombinant human tumor necrosis factor. Proc. Natl. Acad. Sci. U.S.A., 84, 8619-8622.

18. Anna, K., Bereta, J., and Koj, A. (1989): Comparison of the action of interleukin-6, phorbol myristate acetate, and glucagon on the acute phase protein production and amino acid uptake by cultured rat hepatocytes. Ann. N.Y. Acad. Sci., 557, 506-508.

19. Neal, W.C., Schramm, V.L., Kerich, M.J., and Emig, F.A. (1986): Subcellular location of phosphoenolpyruvate carboxykinase in hepatocytes from fed and starved rats. J. Nutr., 116, 1101-1108.

20. Wolfgang, H., Sussmuth, W., O'brien, C., and Seitz, H.J. (1986): Cooperative effect of thyroid and glucocorticoid hormones on the induction of hepatic phosphoenolpyruvate carboxykinase in vivo and in cultured hepatocytes. Eur. J. Biochem., 159, 399-405.

21. Patrick, B.I., and Salavert, A. (1984): Effects of glucagon, dexamethasone and triiodothyronine on phosphoenolpyruvate carboxykinase (GTP) synthesis and mRNA level in rat liver cells. Eur. J. Biochem., 145, 489-497.

22. Teresa, L.A., Beale, E.G., Bar, R.S., and Granner, D.K. (1982): Insulin decreases phosphoenolpyruvate carboxykinase(GTP) mRNA activity by a receptor-mediated process. $J$. Biol. Chem., 257, 35-38.

23. Daryl, G., Andreone, T., Sasaki, K., and Beale, E. (1983): Inhibition of transcription of the phosphoenolpyruvate carboxykinase gene by insulin. Nature, 305, 549-551.

24. Kazuyuki, S., Cripe, T.P., Koch, S.R., Andreone, T.L., Petersen, D.D., Beale, E.G., and Granner, D.K. (1984): Multihormonal regulation of phosphoenolpyruvate carboxykinase gene transcription. J. Biol. Chem., 259, 15242-15251.

25. Bruno, C., Nath, A., Bastian, H., and Jungermann, K. (1988): Regulation of the expression of the phosphoenolpyruvate carboxykinase gene in cultured rat hepatocytes by glucagon and insulin. Eur. J. Biochem., 178, 373-379.

26. Molly, R.H., Stith, R.D., and McCallum, R.E. (1988): Human recombinant IL-1 alters glucocorticoid receptor function in reuber hepatoma cells. J. Immunol., 141, 1522-1528. 